\title{
UDP-Glucuronosyltransferase 1-6
}

National Cancer Institute

\section{Source}

National Cancer Institute. UDP-Glucuronosyltransferase 1-6. NCI Thesaurus. Code C105574.

UDP-glucuronosyltransferase 1-6 (532 aa, $\sim 61 \mathrm{kDa}$ ) is encoded by the human UGT 1A6 gene. This protein is involved in the elimination of phenolic metabolites. 